\title{
HELIANTHEMUM JONIUM (CISTACEAE), A NEW SPECIES IN THE EASTERN ADRIATIC
}

\section{Sandro Bogdanović ${ }^{1,2 *}$, Draško Holcer ${ }^{3}$, Nataša Janev Holcer ${ }^{4} \&$ LULËZIM SHUKA ${ }^{5}$}

\author{
${ }^{1}$ University of Zagreb, Faculty of Agriculture, Department of Agricultural Botany, \\ Svetošimunska 25, 10000, Zagreb, Croatia \\ ${ }^{2}$ Centre of Excellence for Biodiversity and Molecular Plant Breeding, \\ Svetošimunska 25, 10000 Zagreb, Croatia
}

${ }^{3}$ Croatian Natural History Museum, Department of Zoology, Demetrova 1, 10000 Zagreb, Croatia (drasko.holcer@hpm.hr)

${ }^{4}$ Croatian National Institute of Public Health, Rockefellerova 7, 10000 Zagreb, Croatia (natasa.janev@hzjz.hr)

${ }^{5}$ Department of Biology, Faculty of Natural Sciences, Tirana University, Bld. ZOG I, Tirana, Albania (lulezim.shuka@fshn.edu.al)

Bogdanović, S., Holcer, D., Janev Holcer, N., Shuka, L.: Helianthemum jonium (Cistaceae), a new species in the eastern Adriatic. Nat. Croat., Vol. 29, No. 1., 9-18, 2020, Zagreb.

The occurrence of Helianthemum jonium Lacaita \& Grosser ex Bég. in Fiori \& Bég. (Cistacaeae) is reported and documented here for the first time in Croatia and Montenegro, and it is confirmed in the Albanian flora after 80 years. The species grows on sandy soils within maquis and garrigue communities in four Adriatic islands: Vis, Biševo, Hvar and Lopud, and within psammophilous vegetation near Ulcinj in Montenegro and in Hamallaj, north of Durrës in Albania. The morphological relationship with the allied H. leptophyllum Dunal and H. apenninum (L.) Mill. is here briefly discussed. Remarks about its taxonomy, lectotypification, habitat and ecology in the Adriatic region are also provided. The species $H$. jonium was previously known only from the Apennine Peninsula; hence these new eastern Adriatic records extend its distribution area to the east, and it can therefore be considered an amphi-Adriatic endemic element.

Key words: amphi-Adriatic, endemic species, flora, Helianthemum, lectotypification

Bogdanović, S., Holcer, D., Janev Holcer, N., Shuka, L.: Helianthemum jonium (Cistaceae), nova vrsta u istočnom Jadranu. Nat. Croat., Vol. 29, No. 1., 9-18, 2020, Zagreb.

Prisutnost vrste Helianthemum jonium Lacaita \& Grosser ex Bég. in Fiori \& Bég. (Cistacaeae) je ovdje po prvi puta zabilježena i dokumentirana u flori Hrvatske i Crne Gore te potvrđena u flori Albanije nakon 80 godina. Vrsta raste na pješčanim tlima unutar vegetacije makije i gariga na četiri jadranska otoka: Vis, Biševo, Hvar i Lopud te unutar psamofilne vegetacije kod Ulcinja u Crnoj Gori i Hamallaju, sjeverno od Drača u Albaniji. Morfološka sličnost sa srodnim vrstama, $H$. leptophyllum Dunal i $H$. apenninum (L.) Mill. je ovdje ukratko diskutirana. Također se daju napomene o njezinoj morfologiji, lektotipifikaciji, staništu i ekologiji u Jadranskom području. Vrsta $H$. jonium prethodno je bila poznata jedino s Apeninskog poluotoka, a nova nalazišta u istočnom Jadranu pridonose istočnom proširenju granice areala vrste te se ista mora smatrati amfi-jadranskim endemičnim elementom.

Ključne riječi: amfi-jadranski, endemična vrsta, flora, Helianthemum, lektotipifikacija

* corresponding author: sbogdanovic@agr.hr 


\section{INTRODUCTION}

The genus Helianthemum Mill. (Cistaceae) is represented with about 100 taxa in the European flora (Arrington \& Kubitziky, 2003; RAab-Straube, 2018). In particular, about 50 of these occur in the Mediterranean region, with the highest diversity concentrated in the western Mediterranean area, where nearly half of Helianthemum species grow in the Iberian Peninsula (Proctor \& Heywood, 1968; Greuter et al., 1984; Parejo-Farnés et al., 2013). In addition to its remarkable morphological variability, species of this genus show a high degree of diversification with respect to their requirements for environmental conditions. In fact, they colonize extremely differentiated habitats, such as grasslands, sand dunes, forests, garrigues, maquis, rocky outcrops and synantropic stands, as well various types of substrata like limestones, dolomites, marls, gypsum, salt and sand-soils (PAREJo-FARnés et al., 2013).

In the Croatian flora, according to Nikolić $(2019,2020)$, the genus Helianthemum is represented by 11 taxa, of which one is annual and ten are perennials. In neighbouring Italy, thirty taxa are currently recorded (Conti et al., 2005; Peruzzi et al., 2014, 2015; Brullo \& Guarino, 2017; Bartolucci et al., 2018) and among them only five taxa $(H$. farinulentum Lacaita, H. morisianum Bertol., H. oelandicum (L.) Dum. Cours. subsp. nebrodense (Heldr. ex Guss.) Greuter \& Burdet, H. oelandicum (L.) Dum.Cours. subsp. allionii (Tineo) Greuter \& Burdet and H. sicanorum Brullo, Giusso \& Sciandr.) are considered endemics, while H. jonium Lacaita \& Grosser ex Bég. in Fiori \& Bég. is usually excluded, since it is considered a subendemic species. From a taxonomic viewpoint, H. jonium was described by BÉGUINot (1910), using the unpublished name of Lacaita and Grosser quoted in the label of herbarium specimens collected by Lacaita in Apulia (South Italy), which were distributed in many Herbaria as "Schedae ad Floram Italicam Exsiccatam" (FIORI \& BÉGuInot, 1910). Currently, H. jonium was known as a species with a scattered distribution along the Italian peninsula, occurring in Veneto, Emilia Romagna, Molise, Puglia and Basilicata (cf. Brullo et al., 2001; Conti et al. 2005; PerRino \& SignORILe 2009; Brullo \& Guarino 2017). Morphologically, H. jonium is a suffruticous chamaephyte with hairy stem, narrow and elliptical-lanceolate leaves, revolute at margin, green above and pale green below, with yellow flowers and hairy or subglabrous calyx. On account of its opposite stipulate leaves, racemose inflorescences, strongly ribbed calyx, showy coloured petals, and geniculate style exceeding the stamens, it belongs to the H. sect. Helianthemum (cf. López-González, 1993; Soriano, 2002; Alonso et al., 2015).

During recent field trips on the islands of Vis, Biševo and Lopud in Dalmatia, $H$. jonium was discovered for the first time in insular Croatian territory. Afterwards, following herbarium and field investigations its occurrence was verified also in some littoral sites of the Adriatic coast in Montenegro and Albania.

\section{MATERIAL AND METHODS}

In April and May of 2018, previously unknown Helianthemum populations were found within garrigue and maquis communities, developed on sandy soils, on the islands of Vis, Biševo and Lopud in Dalmatia. The collected plants were attributed to $H$. jonium according to Grosser (1903), Proctor \& Heywood (1968), Pignatti (1984) and BRUllo \& GuARINo (2017). 
The inspection of type materials of H. jonium deposited in several virtual herbaria (BM, F, K, and P) confirmed the correct identification of these Dalmatian plants. Afterwards, several other herbarium investigations were performed on the Adriatic Helianthemum material kept in CAT, CNHM, TIR, ZA, ZAGR and ZAHO and also in virtual herbaria of G, GZU, MW, PI and Z. Herbaria acronyms are according to ThieRs (2020). The collected specimens of $H$. jonium from Croatia were scanned, digitalized and inserted according to Bogdanović et al. (2016) in the online Virtual herbarium ZAGR.

To provide a distribution map of $H$. jonium in the Adriatic Basin, previously published localities from the literature data (Beguinot, 1910; Fiori, 1925; Chaytor \& Turrill, 1934; Alston \& Sandwith, 1940; Pignatti 1982; Brullo et al., 2001; Perrino \& Signorile, 2009; Di Pietro \& Misano, 2010; Perrino et al., 2011, 2013; Perrino \& Calabrese, 2014; Brullo \& GuARINO 2017), as well as localities from the herbarium labels of the above mentioned collections were geocoded and are presented on the map (Fig. 1).

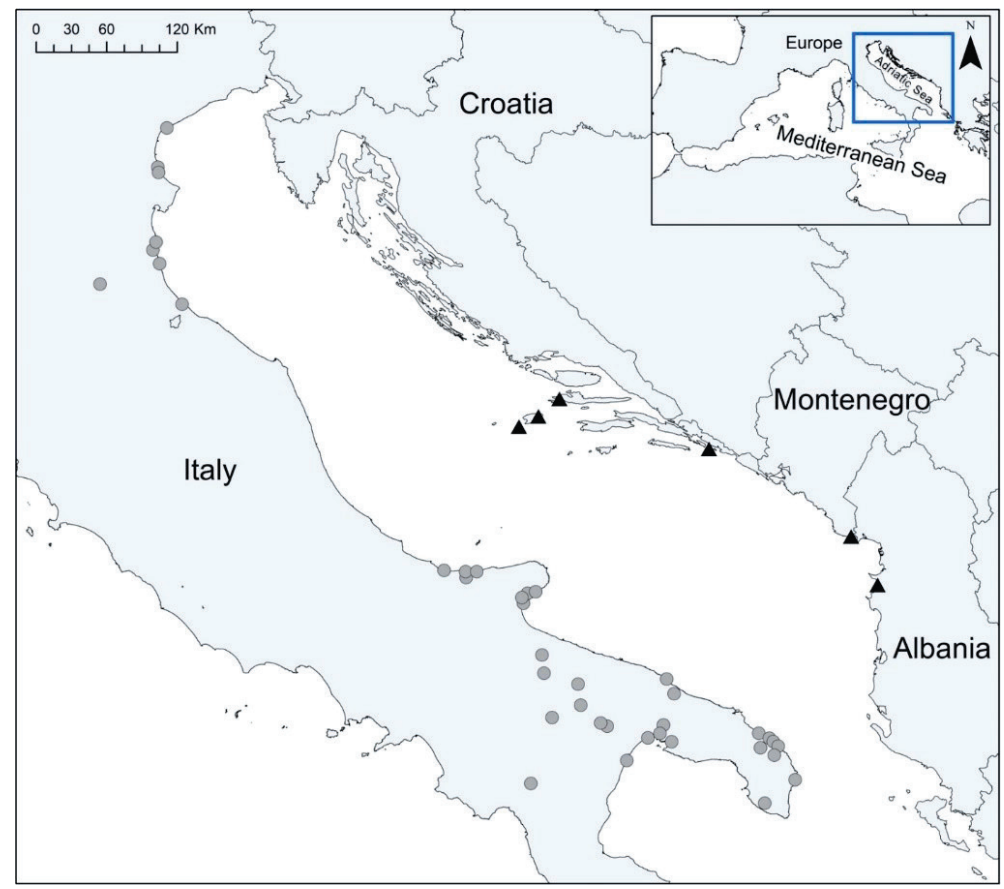

Fig. 1. Distribution map of Helianthemum jonium in the Adriatic Basin based on literature and herbarium data (grey dots) and new findings that are based on recent field observations and herbarium revision (black triangles).

\section{RESULTS AND DISCUSSION}

The occurrence of $H$. jonium is reported and documented here for the first time in Croatia and Montenegro, and it is confirmed in the Albanian flora after 80 years. According to GREUTER et al. (1984) this species shows close relationships with H. leptophyllum Dunal, which represents a species complex distributed in some territories of western Mediterranean, such as Spain, Morocco, Sardinia and Corsica (Greuter \& Raus, 
1982; Greuter et al. 1984; Arrigoni, 2010; RaAb-Straube, 2018). Therefore, H. jonium can be considered an eastern vicariant of the last species, localizing in several Adriatic islands (Vis, Biševo, Lopud and Hvar), in sandy beaches of Montenegro (Ulcinj) and Albania (Hamallaj), where it grows usually on sandy soils within maquis and garrigues, as well as on coastal psammophilous vegetation (Fig. 1).

Helianthemum jonium Lacaita \& Grosser ex Bég. in Fiori \& Bég., Nuovo Gior. Bot. Ital., nov. ser., 17: 609 (1910)

Synonyms: H. leptophyllum sensu E. Groves (Nuovo Giorn. Bot. Ital. 19: 127, 1887), non Dunal. in DC. (Prodr. 1: 279, 1824); H. leptohyllum Dunal var. eulepthophyllum Gross. (Pflanzenreich 14, IV. 193: 69, 1903); H. chamaecistus Mill. var. jonium (Lacaita \& Gross.) Fiori (Nuova Fl. Anal. Ital. 1: 532, 1925).

Typification: Lectotype (here designated) - Apulia. Prov. di Lecce: Taranto, in silvaticis maritimis (macchia mediterranea), loco dicto Pineta del Pantano sociis Erica arborea et Pino halepensi, 29 Apr. 1910, C. Lacaita 1277 (FI 001349!, Fig. 2). Isolectotypes: FI 001395!; FI 001393!; K 000651283!; P 04728870!; BM 000751852!; Z 000002834!; MW 0593629 !. The examination of type materials reveals the existence of several specimens kept in various herbaria (BM, FI, K, MW, P and Z). In accordance with Art. 9.3 of the ICN (Turland et al., 2018), we designate here (Fig. 2) as lectotype Lacaita's specimens kept in the Florence herbarium (FI). All other type materials must be considered as isolectotypes. Regarding the type material of $H$. leptophyllum we have found in de Candolle herbarium (G-DC 00208416!) the original Lagasca material from Spain collected in 1819, that was quoted by Dunal (1824) in the protologue for a description of H. leptophyllum and therefore it is here designated as lectotype.

Morphological description: Perennial plant, ascending to erect, suffruticous, very branched, with branches intricated (Fig. 3A), woody at the base, up to $40 \mathrm{~cm}$ tall, stem and branches with appressed white hairs. Leaves 5-20 mm long, 1-2 mm wide, shortly petiolate, green on adaxial surface, pale green on abaxial surface, narrow, linearelliptical, slightly revolute at the margin, subglabrous, with stipules persistent, linearsubulate, 3-6 mm long (Fig. 3D). Inflorescence racemose, 3-7 flowered, usually unilateral, flower pedicel pendular, 6-12 mm long (Fig. 3B). Inner sepals 5-9 mm long, pubescent, with setulae or sparse erect-patent hairs, that are $0.6-0.8 \mathrm{~mm}$ long. Petals yellow, obovate, up to $10 \mathrm{~mm}$ long, usually with orange dot in the basal part (Fig. 3C). Stamens numerous, filaments unequal, anthers yellow with style exceeding the stamens. Capsule ovoid-globose, puberulous, $4-5 \mathrm{~mm}$ diameter, with style persistent. Seeds yellow or brownish.

Phenology: This species blooms from April to June and fructifies from May to July.

Habitat and ecology: In the eastern Adriatic, H. jonium is a heliophilous species that grows mainly on calcareous and sandy substrates within Mediterranean maquis and garrigues from sea level up to an altitude of $100 \mathrm{~m}$. It can be considered a rare species of the Croatian flora since it was found only at a few localities in Central and South Dalmatia (Fig. 1). On the island of Biševo, H. jonium grows on sandy soils of the abandoned vineyards of Gornja Salbunara within garrigues of Cisto-Ericetalia Horvatić 1958, characterized by Cistus incanus L., C. salviifolius L., C. monspeliensis L., Fumana ericifolia Wallr., F. arabica (L.) Spach, F. laevipes (L.) Spach, Rosmarinus officinalis L., Erica multiflora L. and other shrubs. On the island of Vis, H. jonium is common in north-eastern part, growing on sandy substrates in Malo and Velo Zlopolje along roads and abandoned vineyards, where it is a member of maquis and garrigues, as well as on calcare- 


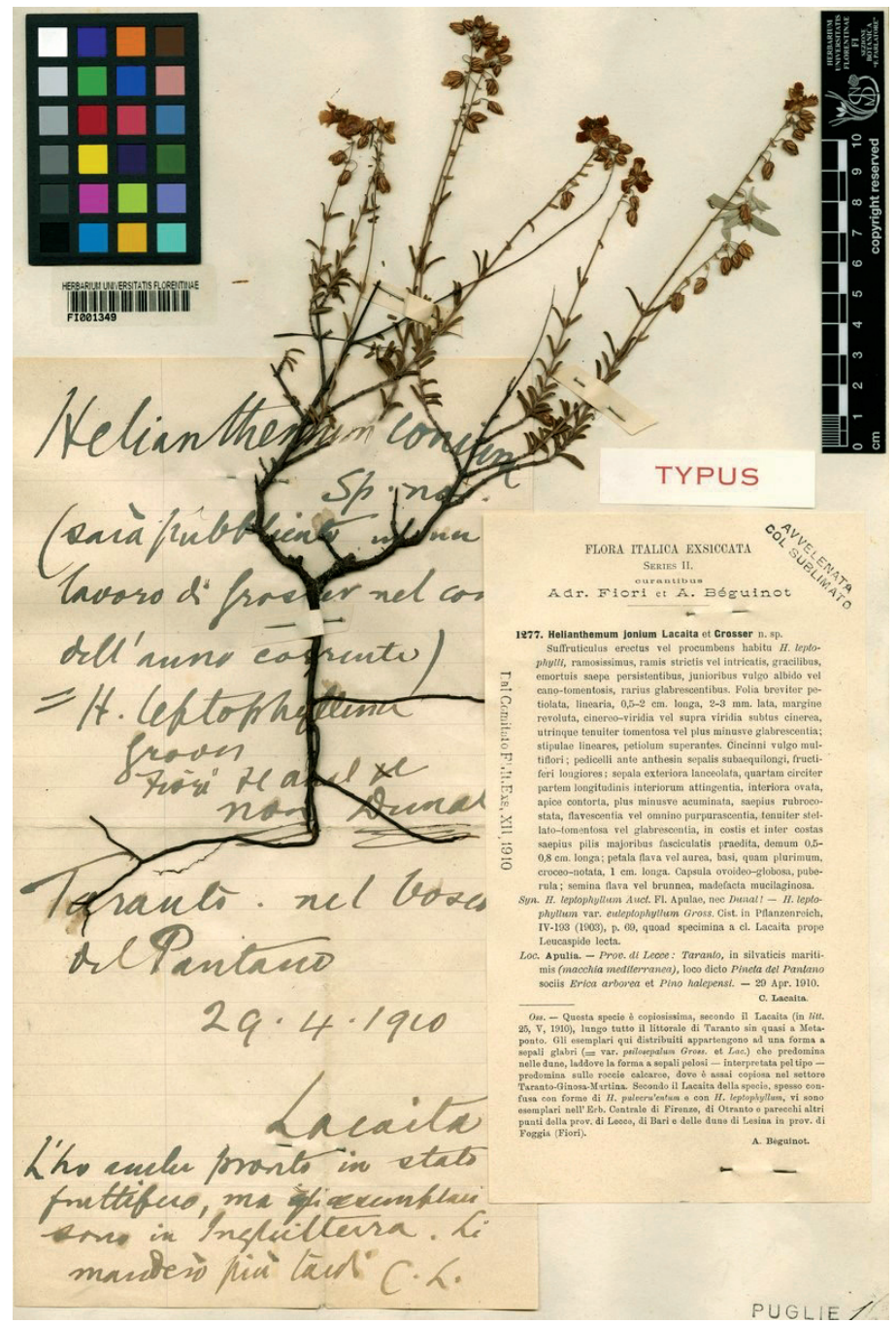

Fig. 2. Lectotype of Helianthemum jonium from FI herbarium (with permission for reproduction of Museo di Storia Naturale, Sezione Botanica "F. Parlatore", http://parlatore.msn.unifi.it).

ous rocks in open grasslands mixed with garrigues as at Rt Stupišće. As concerns the population in Velo Zlopolje, it is the biggest one, with numerous individuals, colonizing sunny sandy slopes of abandoned excavations, where it grows within a community characterized by Alkanna tinctoria Tausch, Ononis natrix L., Foeniculum vulgare Mill., Brachypodium retusum (Pers.) P. Beauv., Helichrysum italicum (Roth.) G. Don and others. On the island of Lopud, H. jonium grows on sandy substrates within garrigues dominated by C. saviifolius, C. incanus, Calicotome villosa (Poir.) Link, Hyparrhenia hirta (L.) Stapf, B. retusum, $H$. italicum and others. In Italian territory, $H$. jonium was surveyed within different habitats showing greater ecological plasticity. According to BRULLO et al. (2001), this species is included among the characteristics of the order Helianthemo 
jonici-Scabiosetalia albae Brullo et al. 2001, which is distributed along the western Adriatic coast of Italy, where it is linked to the psammophilous retrodunal vegetation of the class Euphorbio paraliae-Ammophiletea australis Géhu \& Rivas Martinez in Rivas Martinez et al. 2011. In other localities of Basilicata and Apulia, it was recorded from the calcareous garrigues of Cisto-Micromerietea Oberd. 1954, where it characterized in particular some associations of this class, such as Helianthemum jonii-Corydothymetum capitati Pietro \& Misano 2010 and Helianthemum jonii-Fumanetum thymifoliae Taffetani \& Biondi 1992 (Di Pietro \& Misano, 2010; Perrino \& Calabrese 2014; Brullo \& Guarino, 2017). Finally, in Albania, H. jonium grows within sandy vegetation in the locality Hamallaj (north of Durrës). At this locality $H$. jonium grows on sandy dunes within open places among Juniperus macrocarpa Sm., C. salviifolius, Medicago marina L., A. tinctoria, Juncus acutus L. and others.


Fig. 3. Helianthemum jonium. A) habit, B) part of inflorescence, C) flower, D) leaves (photos by S. Bogdanović and D. Holcer).

Remarks: As already emphasized by Pignatti (1982) and Brullo \& Guarino (2017), morphologically $H$. jonium can be easily confused with $H$. apenninum (L.) Mill. due to its similar habit, woody stem and leaf shape, but the two species differ mainly in petal colour, white in H. apenninum and yellow in H. jonium, as well as in the indumentum of sepals that consist of a dense tomentum with short stellate hairs in H. apenninum and of simple patent hairs in $H$. jonium. Another species closely related to $H$. jonium is $H$. 
leptophyllum, a West Mediterranean species that in Italy occurs in Sardinia. According to The Plant List (2013), H. jonium is treated as a synonym of H. leptophyllum, while many other authors (Pignatti, 1982; Greuter et al., 1984; Brullo \& Guarino 2017; RAab-Straube, 2018) are not of this opinion treating them as two distinct species. At first, Groves (1887), although with much doubt, but at the suggestion of Willkomm, attributed the Italian populations of this species to H. leptophyllum, while subsequently BÉGuinot (1910: 609) described them as a species new to science sub H. jonium Lacaita \& Grosser. In particular it differs from H. leptophyllum mainly in having the upper part of the stem glabrous or subglabrous, narrow linear-elliptical, subglabrous leaves that are 1-2 mm wide, inflorescence 3-7 flowered, sepals purpurescent on ribs, with setulae or sparsely erect-patent hairs. Concerning the occurrence of H. jonium in Morocco, where it was reported by Ruiz De LA Torre (1956), it is now considered to have been a mistake as emphasized by GreUter \& RAUs (1982), since this record had to be more correctly referred to H. leptophyllum.

The previous reports of $H$. jonium in the Balkan Peninsula date back to Chaytor \& Turrill (1934: 438), who quoted it from the sand dunes near Durrës (Durazzo) in Albania referring this population to H. jonium var. psilosepalum Gross. \& Lacaita. Later, this record was confirmed also by Alston \& SANDwith (1940: 149), while BARINA et al. (2018) in their "Checklist of vascular plants of Albania" stress that this is a misidentification, probably to be attributed to H. leptophyllum, but this cannot be verified because the reference herbarium vouchers are missing. Our inspection of the specimens deposited in the herbarium of Tirana (TIR) confirmed only the occurrence of $H$. apenninum and/or $H$. nummularium, as already stated by BARINA et al. (2018). Besides, a field trip was carried out on the sandy vegetation in the locality of Hamallaj (north of Durrës) and H. jonium was found and confirmed after 80 years in Albania. Concerning the chorological status of H. jonium, it can be considered as endemic amphi-Adriatic element.

Specimina visa: ALBANIA: Hamallaj, north of Durrës, sandy dunes, $41^{\circ} 28^{\prime} 51.86^{\prime \prime} \mathrm{N}$, 19³0'26.96”'E, 21.04.2020., L. Shuka s.n. (TIR). CROATIA: Dalmacija, otok Lopud, Šunj, sjeverno od plaže, 12.05.2018., S. Bogdanović s.n. (ZAGR 48010, 47217, 47218, 47219); o. Vis, Podhumlje, 13.03.1972., I. Trinajstić s.n. (CNHM 47501; 600:ZAG; 3465:BOT); o. Hvar, 01.05.1975., I. Trinajstić s.n. (CNHM 47500; 600:ZAG; 3464:BOT); Otok Vis, Velo Zlo polje, 05.05.2018., D. Holcer s.n. (ZAGR 46434, 46433, 46432); Otok Biševo, Gornja Salbunara, 01.05.2018., S. Bogdanović s.n. (ZAGR 46429, 46428, 46427); Dalmacija, otok Vis, Velo Zlo polje, 21.04.2018., S. Bogdanović s.n. (ZAGR 46193, 46192, 46191); Dalmacija, otok Vis, Malo Zlopolje, 22.04.2008., S. Bogdanović, T. Nikolić, I. Boršić s.n. (ZAGR 46189, 46188, 46187); Dalmacija, otok Vis, Rt Stupišće, 21.04.2008., S. Bogdanović, T. Nikolić, I. Boršić s.n. (ZAGR 46186, 46185, 46184, 46178); Dalmacija, otok Biševo, naselje Polje, 115 m/nv, travnjak na pješčanoj podlozi, 16.05.2009., S. Bogdanović s.n. (ZAGR 51618, 51619). ITALY: Italia, Le Cesine (Lecce-Puglia), 13.03.2008, leg. S. Sciandrello \& V. Tomaselli s.n. (CAT 13731); Matera (Basilicata), 09.05.1984, leg. S. Brullo s.n. (CAT 38561); Italia, Basilicata, Dopo Gravina per Potenza, 09.05.1984, leg. S. Brullo, P. Signorello, G. Spampinato s.n. (CAT 38562); Italia, Puglia, Marina di Chiatona (Ta), dune, 16.07.1985, leg. S. Brullo, P. Minissalle, P. Signorello, G. Spampinato s.n. (CAT 38563); Italia, Puglia, Puglie, S. Cataldo, gariga, 17.07.1985, leg. S. Brullo, P. Minissalle, P. Signorello, G. Spampinato s.n. (CAT 38564); Italia, Basilicata, Cava nei pressi di Moliterno, Potenza, 21.06.1995, leg. R. Galesi s.n. (CAT 7139); Marina di Rosolina, 16.6.1989, S. Brullo \& G. Spampinato, s.n. (CAT), Porto Caleri, 16.6.1989, S. Brullo \& G. Spampinato, s.n. (CAT), Casal Rosetti, 17.6.1989, S. Brullo \& G. Spampinato, s.n. (CAT), Cavallino, 17.6 
1989, S. Brullo \& G. Spampinato, s.n. (CAT), Puglia, Marina di Chiatona, 15.7.1985, S. Brullo s.n. (CAT); Italien, Provinz Táranto, Golfo di Táranto, Marina di Genosa, SWRand der Ortschaft, kleine Sandhügel am Rande des Pinetums, 15.04.2003, leg. R. Karl (GZU 241739, 241740); Apulia, Proc. di Lecce: Taranto, in aridis saxosis calcareis prope locum dictum Leucaspide, alt. cir. 50 m, 07.1908, leg. C. Lacaita 1460 (P 04728871); Pineta el Pantano prope Taranto, in silvaticis maritimis solo arenoso, est forma «psilosepalum», 29.04.1910, leg. C. Lacaita s.n. (P 06716346); Gravinola prope Taranto, in sax. calc., c. 30 m, 18.03.1906, leg. C. Lacaita s.n. (P 06716345); Apulia, Proc. di Lecce: Taranto, in aridis saxosis calcareis prope locum dictum Leucaspide, alt. cir. 50 m, 07.1908, leg. C. Lacaita 1460 (K 000651284 ); Leucaspide, near Tarnato (s. Italy), 04.1881, leg. C. Lacaita s.n. (sub Helianthemum leptophyllum Dunal) (K 000651286; 000651285); Gravina di Petruscio (Mottola, TA), vegetazione casmofitica con Campanula versicolor, Scrophularia lucida e garighe con Salvia fruticosa, 120 m s.l.m., 09.05.0018, leg. F. Roma-Marzio, M. D'Antraccoli s.n. (PI 018365, 018364); Gravina di Leucaspide (Statte, TA), vegetazione casmofitica, 120 m s.l.m., 10.05.2018, leg. F. Roma-Marzio, M. D'Antraccoli s.n. (PI 018515); Masseria Amastuola (Crispiano, TA), gariga a Cistus sp.pl. e Thymbra capitata e pinete aperte, $130 \mathrm{~m}$ s.l.m., 10.05.2018, leg. F. Roma-Marzio, M. D'Antraccoli s.n. (PI 018440). MONTENEGRO: Ulcinj-Velika plaža, 03.10.1977., I. Trinajstić s.n. (CNHM 47493; 600:ZAG; 3457:BOT).

\section{ACKNOWLEDGEMENTS}

We would like to thank curators of herbaria CAT, CNHM, FI, ZA, ZAGR and ZAHO. Special thanks to curators, Dr. Suzana Buzjak for valuable support in searching of Trinajstićs materials in CNHM and to Dr. Chiara Nepi for providing us with type specimens from FI herbarium. Thanks to our colleague from CAT herbarium, Prof. Salvatore Brullo and Dr. Saverio Sciandrello, for sending us comparative materials of $H$. jonium from Italy. We are grateful to the anonymous reviewers who improved the quality of our manuscript.

Received April 2, 2020

\section{REFERENCES}

Alonso, A., Crespo, M.B., JuAni, A. \& SAez, L., 2015: Helianthemum (sect. Helianthemum) raskebdanae (Cistaceae), a new species from northeastern Morocco. Phytotaxa 207, 253-264.

Alston, A. H. G \& Sandwith, N. Y., 1940: Results of two botanical expeditions to South Albania. The Journal of Botany, British and Foreign (London) 78, 119, 147, 167, 193, 219, 232.

Arrigoni, P. V., 2010: Flora dell'isola di Sardegna 2. Carlo Delfino, Sassari.

Arrington, J. M. \& KubitzKi, K., 2003: Cistaceae. In: KubitzKi, K. (ed.), The families and genera of vascular plants. IV flowering plants dicotyledons Malvales, Capparales and non-betalain Caryophyllales. Springer, Berlin. p. 62-70.

Barina, Z., Somogyi, G., Pifkò, D., \& RakaJ, M., 2018: Checklist of vascular plants of Albania. Phytotaxa 378, 1-339.

Bartolucci, F., Peruzzi, L., Galasso, G., Albano, A., Alessandrini, A., Ardenghi, N. M. G., Astuti, G., Bacchetta, G., Ballelli, S., Banfi, E., Barberis, G., Bernardo, L., Bouvet, D., Bovio, M., Cecchi, L., Di Pietro, R., Domina, G., Fascetti, S., Fenu, G., Festi, F., Foggi, B., Gallo, L., Gottschlich, G., Gubellini, L., Iamonico, D., Iberite, M., Jiménez-Mejías, P., Lattanzi, E., Marchetti, D., Martinetto, E., Masin, R. R., Medagli, P., Passalacqua, N. G., Peccenini, S., Pennesi, R., Pierini, B., Poldini, L., Prosser, F., Raimondo, F. M., Roma-Marzio, F., Rosati, L., Santangelo, A., Scoppola, A., Scortegag- 
na, S., Selvaggi, A., Selvi, F., Soldano, A., Stinca, A., Wagensommer, R. P., Wilhalm, T. \& Conti, T., 2018: An updated checklist of the vascular flora native to Italy. Plant Biosystems 152, 179-303.

Béguinot, A., 1910: 1277. Helianthemum jonium Lacaita et Grosser n. sp. In: Fiori, A., \& BÉguinot, A. (eds.), Schedae ad Floram Italicam exsiccatam, Centuriae XIII-XIV. Nuovo Giornale Botanico Italiano. Nuova serie 17, 609-610.

Bogdanović, S., Britvec, M., Ljubičić, I., Dujmović Purgar, D. \& Vitasović Kosić, I., 2016: Herbarium ZAGR of the Faculty of Agriculture (Zagreb, Croatia). Agriculturae Conspectus Scientificus 81, 1-5.

Brullo, S. \& Guarino, R., 2017: Helianthemum Mill. In: Pignatti, S. (ed.), Flora d'Italia vol. 2 (seconda edizione). Edagricole. p. 1054-1064.

Brullo, S., Giussso del Galdo, G., Siracusa, G. \& Spampinato, G., 2001: Considerazioni fitogeografiche sulla vegetazione psammofila dei litorali italiani. Biogeografia 22, 93-137.

Chaytor, D. A. \& Turrill, W. B., 1934: On the Flora of the Nearer East XV. A contribution to the Flora of Central Albania. Bulletin of Miscellaneous Information 10, 437-443.

Conti, F., Abbate, G., Alessandrini, A. \& Blasi, C. (eds.), 2005: An annotated checklist of the Italian vascular flora. Palombi Editori, Roma.

Di Pietro, R. \& Misano, G., 2010: Shrubland and garrigue vegetation in the "Gravine" gorges (Apulia region, south-eastern Italy). Acta Botanica Gallica 157, 195-229.

Dunal, F., 1824: Cistineae. In: Candolle, A. P. De, (ed.), Prodromus systematis naturalis regni vegetabilis, 1: 263-286. Parisiis, Sumptibus Sociorum Treuttel et Würtz, Parisiis.

Fiori, A. \& BÉguinot, A., 1910: Schedae ad Floram Italicam Exiccatum series 2., Centuriae XIII-XIV. Nuovo Giornale Botanico Italiano. Nuova serie 17, 563-668.

Fiori, A., 1925: Nuova Flora Analitica d'Italia vol. 1. Edagricole, Bologna.

Greuter, W. \& Raus, Th. (ed.) 1982: Med-Checklist Notulae, 5. Willdenowia 12, 33-46.

Greuter, W., Burdet, H. M. \& Long, G., 1984: Med-Checklist vol. 1. A critical inventory of vascular plants of the circummediterranean countries. Conservatoire et Jardin botaniques de la Ville de Geneve \& Secretariat MedChecklist, Geneve and Berlin.

Grosser, W., 1903: Cistaceae. In: Engler, A. (ed.), Pflanzenreich 14 (IV. 193): 1-161. Breitkopf \& Härtel. Leipzig.

Groves, E., 1887: Flora della costa meridionale della terra d'Otranto. Nuovo Giornale Bot. Ital. 19, 110-219.

López González, G., (1993) Helianthemum Mill. In: Castroviejo, S., Aedo, C., Cirujano, S., Laínz, M., Montserrat, P., Morales, R., Muñoz Garmendia, F., Navarro, C., Paiva, J. \& Soriano, C. (Eds.) Flora iberica 3. Real Jardín Botánico, CSIC, Madrid, pp. 365-421.

Nikolić, T., (ed.) 2020: Flora Croatica Database. University of Zagreb, Faculty of Science, Department of Botany. Accessed $6^{\text {th }}$ March 2020

Nikolić, T., 2019: Flora Croatica vol. 4. Alfa d.d., Zagreb.

Parejo-Farnés, C., Albaladejo, R. G., Arroyo, J. \& Aparicio, A., 2013: A phylogenetic hypothesis for Helianthemum (Cistaceae) in the Iberian Peninsula. Botanica Complutensis 37, 83-92.

Perrino, E. V. \& Calabrese, G., 2014: Vascular flora of the ancient olive groves of Apulia (southern Italy). Natura Croatica 23, 189-218.

Perrino, E. V. \& Signorile, G., 2009: Costa di Monopoli (Puglia): checklist della flora vascolare. Informatore Botanico Italiano 41, 263-279.

Perrino, E. V., Calabrese, G., Ladisa, G., Viti, R., Mimiola, G., 2011: Primi dati sulla biodiversità della flora vascolare di oliveti secolari in Puglia. Informatore Botanico Italiano 43, 39-64.

Perrino, E. V., Signorile, G. \& Marvulli, M., 2013: A first checklist of the vascular flora of the Polignano a Mare coast (Apulia, southern Italy). Natura Croatica 22, 295-318.

Peruzzi, L., Conti, F. \& Bartolucci, F., 2014: An inventory of vascular plants endemic to Italy. Phytotaxa $168,1-75$.

Peruzzi, L., Domina, G., Bartolucci, F., Galasso, G., Peccenini, S., Raimondo, F.M., Albano, A., Alessandrini, A., Banfi, E., Barberis, G., Bernardo. L., Bovio, M., Brullo, S., Brundu, G., Brunu, A., Camarda, I., Carta, L., Conti, F., Croce, A., Iamonico, D., Iberite, M., Iiriti, G., Longo, D., Marsili, S., Medagli, P., Pistarino, A., Salmeri, C., Santangelo, A., Scassellati, E., Selvi, F., Soldano, A., Stinca, A., Villani, M, Wagensommer, R. P. \& Passalacqua, N. G., 2015: An inventory of the names of vascular plants endemic to Italy, their loci classici and types. Phytotaxa 196, 1-217.

Pignatti, S., 1982: Flora d'Italia vol. 2. Edagricole, Bologna. 
Proctor, M. C. F. \& Heywood, V. H., 1968: Helianthemum Miller In: Tutin, T. G., Heywood, V. H., Burges, N. A., Moore, D. M., Valentine, D. H., Walters, S. M., WebB, D. A. (eds), Flora Europaea, $2^{\text {nd }}$ edn. Cambridge University Press, Cambridge. p. 286-291.

RaAb-Straube, E., 2018: Cistaceae. In: Euro+Med Plantbase - the information resource for Euro-Mediterranean plant diversity. (accessed 18.11.2018. http://ww2.bgbm.org/EuroPlusMed/).

Ruiz De La TorRe, J., 1956: La vegetatión natural del Norte de Marruecos y la elección de especies para su repoblación forestal. Servicio de Montes, Centro Investigaciones y Experiencias Forestales, Larache.

Soriano, I., 2002: Helianthemum Mill. In: Valdés, B., Rejdali, M., Achal El Kadmiri, A., Jury, J.L. \& MontSERRAT, J.M. (Eds.) Checklist of vascular plants of N Morocco with identification keys 1. CSIC, Madrid, pp. 204-209.

The Plant List, 2013: The Plant List, Version 1.1. Published on the Internet; http://www.theplantlist.org (accessed $1^{\text {st }}$ February 2019)

ThIERs, B., 2020: Index herbariorum, a global directory of public herbaria and associated staff. New York Botanical Garden's Virtual Herbarium. Accessed 20 ${ }^{\text {th }}$ April 2019 from http://sweetgum.nybg.org/ih/.

Turland, N. J., Wiersema, J. H., Barrie, F. R., Greuter, W., Hawksworth, D. L., Herendeen, P. S., Knapp, S., Kusber, W.-H., Li, D.-Z., Marhold, K., May, T. W., Mc Neill, J., Monro, A. M., Prado, J., Price, M. J. \& SмiтH, G. F., 2018: International Code of Nomenclature for algae, fungi, and plants (Shenzhen Code). Regnum Vegetable 159, 1-254. 